\title{
Analyzing of Urine 3-Hidroxy Propil Mercapturic Acid on Cyclophosphamide Induced Rat to Determine Ameliorating Effect of Leucaena leucocephala (Lam.) de Wit Seed Extract
}

\author{
Sri Wardatun ${ }^{1,2}$, Yahdiana Harahap ${ }^{1,3, *}$, Noorwati Sutandyo ${ }^{4,5}$, Abdul Mun'im ${ }^{1}$
}

Sri Wardatun 1,2 , Yahdiana

Harahap ${ }^{1,3, *}$, Noorwati Sutandyo ${ }^{4,5}$, Abdul Mun'im ${ }^{1}$

'Faculty of Pharmacy, Universitas Indonesia, Depok, INDONESIA.

2Program Study of Pharmacy, Universitas Pakuan, Bogor, INDONESIA.

${ }^{3}$ Faculty of Pharmacy, Republic of Indonesia Defense University, Bogor, INDONESIA.

${ }^{4}$ Dharmais, Cancer Hospital, Jakarta, INDONESIA.

${ }^{5}$ Faculty of Medicine, Universitas Indonesia,

Depok, INDONESIA

\section{Correspondence}

Yahdiana Harahap

Faculty of Pharmacy, Universitas

Indonesia, Depok; Faculty of Pharmacy,

Republic of Indonesia Defense University,

Bogor, INDONESIA.

E-mail: yahdiana@farmasi.ui.ac,id

History

- Submission Date: 26-09-2021;

- Review completed: 06-10-2021;

- Accepted Date: 14-10-2021.

DOI : 10.5530/pj.2021.13.197

Article Available online

http://www.phcogj.com/v13/i6

Copyright

(C) 2021 Phcogi.Com. This is an openaccess article distributed under the terms of the Creative Commons Attribution 4.0 International license.

\begin{abstract}
Background: A 70\% ethanolic extract of Leucaena leucocephala (Lam.) de Wit seeds contain a certain amount of sulfhydryl active compounds and potential for ameliorated cyclophosphamide side effects. Objective: The aim of this study was to analyze of urine 3-hidroxy propil mercapturic acid (3-HPMA) in a rat model for cyclophosphamide-induced hemorrhagic cystitis to determine the effect of Leucaena leucocephala (Lam.) de Wit seeds extract. Materials and methods: The levels of urine 3-hidroxy propil mercapturic acid was measured using LCMS/MS. Urine preparation was carried out by dilution (1:5) with mobile phase and contained a deuteurated internal standard. The LC separation was performed using a $\mathrm{C}_{18}$ column $(1.7 \mu \mathrm{m} ; 2.1 \mathrm{~mm} \times 100 \mathrm{~mm})$. The mobile phase consisted of formic acid $(0.1 \%)$ and formic acid $(0.1 \%)$ in acetonitrile $(90: 10 \mathrm{v} / \mathrm{v})$, as a starting gradient at flow rate of $0.2 \mathrm{ml} / \mathrm{min}$ with total run $7 \mathrm{~min}$. Results: The lower limit of quantification was $40 \mathrm{ng} / \mathrm{ml}$ and the linear extended to $20,000 \mathrm{ng} / \mathrm{ml}$. The method has been successfully to be applied in determined of rat urine 3-HPMA. The results showed that the $70 \%$ ethanolic extract of seeds can increased the amount of 3-HPMA in rat urine. Conclusion: The $70 \%$ ethanolic extract of seeds displayed a potential ameliorating effect against cyclophosphamide side effects. Key words: Leucaena leucocephala (Lam.) de Wit, Cyclophosphamide, 3-Hidroxypropil mercapturic acid, Urine.
\end{abstract}

\section{INTRODUCTION}

Cyclophosphamide is a chemotherapy that is widely used to fight various types of cancers. ${ }^{1,2}$ However, its administration often causes side effects, including hemorrhagic cystitis. ${ }^{2-5}$ Approximately $10 \%-25 \%$ of patients develop hemorrhagic cystitis 1 week to several months after cyclophosphamide administration. ${ }^{6}$ Hemorrhagic cystitis occurs in $10 \%$ of patients receiving normal doses and $40 \%$ of patients receiving high doses of cyclophosphamide, despite precautions. ${ }^{7,8}$ Acrolein is a metabolite of cyclophosphamide, and it was identified as being responsible for causing hemorrhagic cystitis. ${ }^{1,2}$

The incidence of hemorrhagic cystitis can be reduced by stopping treatment or reducing the dose of the drug, and it can also be decreased by $6 \%-50 \%$ with bladder irrigation and mesna administration..$^{1,4,9,10}$ Mesna, amifostine, and $\mathrm{N}$-acetylcysteine are sulfhydryl compounds that are administered to avoid hemorrhagic cystitis. ${ }^{1,2,11}$ Consumption of nutrients that induce glutathione S-transferase, diallyldisulfide, and S-allylcysteine compounds can reduce the effect of hemorrhagic cystitis in mice. ${ }^{12-17}$ Leucaena leucochepala (Lam) de Wit seeds contain sulfhydryl compounds at 1.5 $\mathrm{mmol} / 100 \mathrm{~g}$ dry seeds. ${ }^{18}$ The content of sulfhydryl compounds in seeds can potentially be used as an alternative medicine to avoid the occurrence of hemorrhagic cystitis. Leucaena leucochepala (Lam) de Wit seeds are easy to find and occur in abundance; their use as a source of nutrients to produce sulfhydryl compounds can increase value. ${ }^{17,18}$
The potential of natural ingredients in improving the side effects of cyclophosphamide therapy has been widely investigated, but their association with metabolite levels has not been studied. ${ }^{19}$ This study was conducted to analyze the metabolites produced from cyclophosphamide by measuring 3-hydroxypropyl mercapturic acid in rat urine after administration of Leucaena leucochepala (Lam.) de Wit seed extract and cyclophosphamide. Acrolein analysis was determined for 3-hydroxy propyl mercapturic acid because acrolein has a small half-life and is easily metabolized and excreted in the urine in the form of 3-HPMA, so analysis as 3-HPMA is more accurate than analysis in the form of acrolein. ${ }^{20-22}$

\section{MATERIALS AND METHODS}

\section{Chemical and extract}

First, 3-HPMA (95\% purity) and internal standard (IS) 3-hydroxypropyl mercapturic acid-d3 (3-HPMA-d3, chemical purity, 98\%; isotopic purity, 95\%) were obtained from Toronto Research Chemicals (Canada) as dicyclohexylammonium salts. Furthermore, creatinine kit (Greiner Diagnostic $\mathrm{GmbH}$, Germany), HPLC grade-acetonitrate, formic acid, and ethanol were purchased from Merck Indonesia. All other chemicals used were analytical grade. Cyclophosphamide injection (Dankos, Indonesia) were purchased from Dharmais, Cancer Hospital, Jakarta, Indonesia, Leucaena leucocephala (Lam.) de Wit seed extract was prepared according to the procedure detailed in Wardatun et al. ${ }^{24}$.

Cite this article: Wardatun S, Harahap Y, Sutandyo N, Mun'im A. Analyzing of Urine 3-Hidroxy Propil Mercapturic Acid on Cyclophosphamide Induced Rat to Determine Ameliorating Effect of Leucaena leucocephala (Lam.) de Wit Seed Extract. Pharmacogn J. 2021;13(6)Suppl: 15491556. 


\section{Animal and experimental design}

Thirty male Sprague-Dawley rats were obtained from PT Medical Technology Indonesia, Indonesia. Animals were maintained at $24^{\circ} \mathrm{C} \pm$ 1 at a 12:12 h dark/light cycle. The animals have give food and water ad libitum but $8 \mathrm{~h}$ before tested, the food were deprived. All experimental procedures were approved by the ethics committee of the Faculty of Medicine, Universitas Indonesia (No. KET.298a/UN2.FI/ETIK/ PPM.00.02/2020).

The rats were acclimatized in a 1-week and were divided into three groups randomly. The first group is a negative control and was treated with aquadest orally for 1 week. The second group received aquadest orally for 1 week and $1 \mathrm{~h}$ prior to being treated intraperitoneally with cyclophosphamide $(50 \mathrm{mg} / \mathrm{kg})$ on the last day, according to El-Sebaey et al. ${ }^{17}$ The third group was received ethanolic extract seeds once daily for 7 consecutive days at a dose of $300 \mathrm{mg} / \mathrm{kg}$ and $1 \mathrm{~h}$ prior to injection of cyclophosphamide on the last day. ${ }^{17}$

\section{Urine sample collection}

After treatment, all rats were placed in a standard methabolic cage for urine collection. Urine was collected within $24 \mathrm{~h}$. Only regular water was supplied during the experiments. Occasionally, urine was collected by manually pressing the bladder. The urine were stores at $-20^{\circ} \mathrm{C}$.

\section{Specimen kidney collection}

After collecting urine within 24 hours, the rats were sacrified using ketamine $(80 \mathrm{mg} / \mathrm{kg})$ and xylazine $(10 \mathrm{mg} / \mathrm{kg})$ intraperitoneally. Specimen from kidney was fixed with $10 \%$ neutral buffer solution of formaline for histhopathological examination.

\section{Analysis of creatinine}

Creatinine levels were determined using a creatinine kit (Greiner Diagnostic GmbH, Germany), which was analyzed with Photometer 5010. Urine creatinine was analyzed after 20 dilutions. The alkaline picrate solution was prepared according to the manual procedure by adding one part of $\mathrm{NaOH}(160 \mathrm{mmol} / \mathrm{L})$ with $4.0 \mathrm{mmol} / \mathrm{L}$ picric acid. The creatinine standard contained $2.0 \mathrm{mg} / \mathrm{dL}$. Fifty $\mu \mathrm{l}$ of urine sample solution and standard were added to each sample with $1.0 \mathrm{~mL}$ of reagent solution. The solution was mixed and stored at $37^{\circ} \mathrm{C}$ for $1 \mathrm{~min}$ and then measured to $492 \mathrm{~nm}$ with a distilled water blank solution. The second measurement was carried out 2 min after the first measurement. The difference between the first and second absorption was used to analyze the sample.

\section{Calibration standard and quality control samples}

A stock solution of 3-HPMA was prepared by diluting $10 \mathrm{mg}$ 3-HPMA in aquadest to obtain $1,000 \mu \mathrm{g} / \mathrm{ml}$, which was further diluted with authentic urine to obtain the following concentrations: 20,$000 ; 10,000$; 5,000; 1,000; 500; 100 and $40 \mathrm{ng} / \mathrm{ml}$. Furthermore, 3-HPMA-d3 was prepared at $1,000 \mu \mathrm{g} / \mathrm{ml}$ in aquadest and further diluted to obtain 10 $\mu \mathrm{g} / \mathrm{ml}$. Quality control samples were prepared at 200; 8,000 and 16,000 $\mathrm{ng} / \mathrm{ml}$ in authentic urine for QCL, QCM, and QCH, respectively. It was used for method validation.

\section{Liquid chromatography-mass spectrometry instrument and conditions}

The LC-MS/MS system consisted of a binary pump, an autosampler, and a $\mathrm{C}_{18}$ column $(1.7 \mu \mathrm{m}, 100 \mathrm{~mm} \times 2.1 \mathrm{~mm}$, Waters Milford, MA, USA). The mass spectrometry detection method was quadrupole (Xevo TQD, Waters) in ESI positive. The optimum chromatographic conditions was achieved by gradient elution. Eluent A consisted of $0.1 \%$ formic acid and eluent B consisted of $0.1 \%$ formic acid on acetonitrile. At time 0, 90\% eluent A and 10\% eluent B were flushed through the column. After $2 \mathrm{~min}$, eluent $\mathrm{A}$ was decreased to $10 \%$ and was maintained for 2 min. Furthermore, the composition of the mobile-phase was set back at $90 \%$ eluent $\mathrm{A}$ at $0.1 \mathrm{~min}$, remaining as such for $7 \mathrm{~min}$ of the run. The flow rate was $0.2 \mathrm{ml} / \mathrm{min}$, and the column temperature was $40^{\circ} \mathrm{C}$. The mass transition of 3-HPMA was monitored at $\mathrm{m} / \mathrm{z} 221.968>90.993$, and it was labeled 3-HPMA at $\mathrm{m} / \mathrm{z} 225.032>$ 117. The injection volume was $10.0 \mu$ l. The mass spectrum conditions are shown in Table 1. The data were processed using Masslynx version 4.1 software (Waters, USA).

\section{Sample preparation}

The urine samples were filtrated with a nylon syringe filter measuring $0.2 \mu \mathrm{m}$. Then $100 \mu \mathrm{l}$ of urine sample had added to it $10 \mu \mathrm{l}$ of formic acid and $50 \mu \mathrm{l}$ of labelled 3-HPMA at $10 \mu \mathrm{g} / \mathrm{ml}$. Mobile phase (Phase A:B; 90:10) was added to the resulting solutions until $500 \mu \mathrm{l}$. The mixture was vortex mixed for $2 \mathrm{~min}$ and centrifuged at 5,000 rpm for $10 \mathrm{~min}$. Furthermore, $10 \mu \mathrm{l}$ of aliquot was injected into the LC-MS/MS.

\section{Validation procedure}

Validation of the quantitative LCMS/MS method was performed by means of linearity, accuracy, precision, selectivity, carry over, integrity dilution, matrix effect, and stability. ${ }^{24,25}$ A partial validation was performed by means of linearity, accuracy, precision, and selectivity with the rat urine matrix. Furthermore, the assay application was demonstrated.

\section{Statistical analysis}

Statistical analyses were conducted using SPSS 26 (BMI, New York) to test for significant differences among treatments. $\mathrm{P}<0.05$ was chosen as the level of significance.

\section{RESULTS}

\section{Analytical method}

The results of the detection using a mass spectrometer showed fragmentation of $\mathrm{m} / \mathrm{z} 221.968>90.993$ for 3-HPMA and 225.032>117 for 3-HPMA-d3. Analytical conditions of mass spectrometry (Table 1). The analytical method for 3-HPMA was developed by Harahap et $a l{ }^{26}$ Urine samples were prepared using a dilution system. The direct dilution method is a procedure for diluting a urine sample with a number of solutions. This method is easy and economical and is the main choice for analyzing urine with high analyte concentrations. The compounds 3-HPMA and 3-HPMA-d3 are water-soluble compounds, so there was no need for preparation using liquid-liquid extraction.

\section{Validation assay}

Selectivity tests were conducted to determine the interference caused by endogenous matrix compounds or other compounds in the sample. These tests were carried out on blank samples and samples at LLOQ concentrations, both for analyte and internal standards. The interference in the urine matrix meets the predetermined requirements if interference in analyte (3-HPMA) is not more than $20 \%$ and $5 \%$ for the internal standard (3-HPMA-d3). Chromatogram ions of 3-HPMA and IS of blank urine are depicted in Figures 1 . The calibration curve was obtained by dilution of 3-HPMA $1,000 \mu \mathrm{g} / \mathrm{ml}$, and it had a calibration curve in concentrations of 40,100,500,1,000,5,000,10,000, and 20,000 $\mathrm{ng} / \mathrm{mL}$, as well as for blank and zero samples. Intraassay and interassay accuracy and precision were determined within 2 days using a quality control sample solution at low, medium, and high concentrations (Table 2).

The carry-over test was implemented to ensure that there was no interference in the retention time of the analyte after analysis of a high concentration sample. This test was carried out by injecting a sample 
Table 1: Analytical Conditions for Mass Spectrometry.

\begin{tabular}{|c|c|c|c|c|c|c|c|}
\hline \multirow[t]{2}{*}{ Compound } & \multirow{2}{*}{$\begin{array}{l}\text { Ion fragment } \\
(\mathrm{m} / \mathrm{z})\end{array}$} & \multirow{2}{*}{$\begin{array}{l}\text { Ionization } \\
\text { mode }\end{array}$} & \multirow{2}{*}{$\begin{array}{c}\text { Capillary } \\
\text { voltage (KV) }\end{array}$} & $\begin{array}{l}\text { Temperature of } \\
\text { gas desolvation }\end{array}$ & $\begin{array}{c}\text { Flow rate of gas } \\
\text { desolvation }\end{array}$ & Orifice voltage & \multirow{2}{*}{$\begin{array}{c}\text { Collision } \\
\text { voltage (V) }\end{array}$} \\
\hline & & & & $\left({ }^{\circ} \mathrm{C}\right)$ & (L/hour) & (V) & \\
\hline 3-HРMA & $221.968>90.993$ & \multirow{2}{*}{$\mathrm{ESI}+$} & \multirow{2}{*}{3.5} & \multirow{2}{*}{350} & \multirow{2}{*}{650} & 20 & 22 \\
\hline 3-HPMA-d3 & $225.032>117.00$ & & & & & 18 & 14 \\
\hline
\end{tabular}

Table 2: Accuracy and Precision Data.

\begin{tabular}{|c|c|c|c|c|c|c|}
\hline \multirow{2}{*}{ Analyte } & \multicolumn{2}{|c|}{ Concentration } & \multicolumn{2}{|c|}{ Precision (\%CV) } & \multicolumn{2}{|c|}{ Accuracy (\%bias) } \\
\hline & QC & $\mathrm{ng} / \mathrm{ml}$ & intra assay & inter assay & intra assay & inter assay \\
\hline \multirow[t]{4}{*}{ 3-НРMA } & LLOQ & 40 & 1.647 & 2.977 & 14.487 & 14.971 \\
\hline & QCL & 200 & 6.618 & 7.273 & -6.351 & -6.763 \\
\hline & QCM & 8000 & 9.672 & 10.610 & -0.606 & -3.510 \\
\hline & $\mathrm{QCH}$ & 16000 & 5.052 & 8.431 & 4.140 & -5.493 \\
\hline
\end{tabular}

Table 3: Sample Stability Data for Short- and Long-Term Storage.

\begin{tabular}{lccccc}
\hline & & Concentration & Measured & \\
& & $n g / m l$ & Mean \pm SD $(\mathbf{n}=3)$ & RSD (\%) \\
\hline short term stored at room & QCL & 200 & $212.824 \pm 3.024$ & 6.412 & 1.421 \\
temperature $\left(20^{\circ} \mathrm{C}\right)$ & QCH & 16000 & $16464.451 \pm 796.955$ & 2.902 & 4.84 \\
Long term stored at & QCL & 200 & $191.963 \pm 11.610$ & 6.412 & -4.106
\end{tabular}

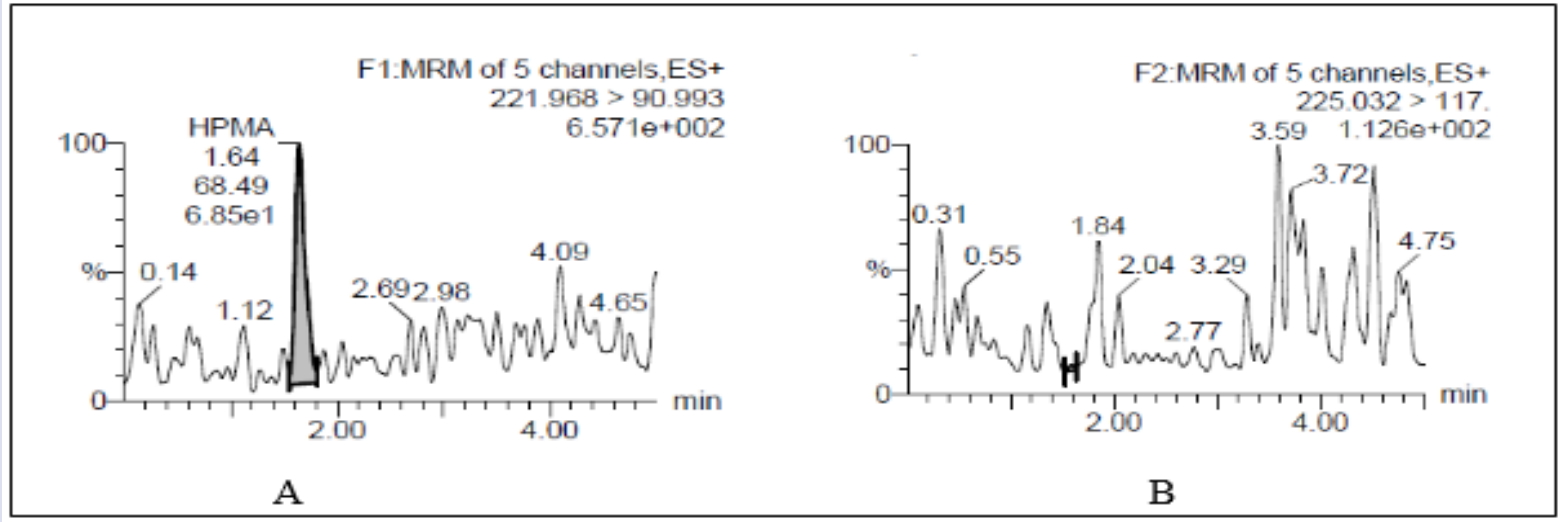

Figure 1: Chromatogram ion 3-HPMA (A) and 3-HPMA-d3 (B) in blank urine.

with a concentration of ULOQ and then observing interference in the retention time of the next injected blank sample. ${ }^{24}$ The results of the carry-over test on the sample showed that the carry over in the blank and LLOQ after being injected with ULOQ was an average of $6.973 \%$, while the average was $0.008 \%$ in the internal standard. This results showed that there was no carry over in this analysis system. The matrix effect is determined in analyses involving mass spectrometry, especially when using the ESI mode, and is observed as an increase or decrease in the ion response. The test results revealed that the standard normalized matrix effects for 3-HPMA on QCL and QCH were $0.868 \pm 0.028$ and $0.957 \pm 0.015$, respectively.

Stability tests were implemented to ensure that every step taken from sample preparation to analysis, including storage, did not affect the analyte concentration in the sample. Stability test were determined for stock solution of analyte and internal standard as well as working solution at low and high concentration. The results of stability test indicated that all solution were stable during preparation and storage period (Table 3). The results of partial validation using rat urine demonstrated that the validation assay results fulfilled the requirements.

\section{Creatinine levels}

The results of the determination of creatinine levels showed that creatinine levels in Groups 1, 2, and 3 were $6.46 \pm 1.61,5.76 \pm 1.88$, and $5.51 \pm 1.50 \mathrm{mg} / \mathrm{dL}$, respectively (Figure 2). The results of statistical analysis revealed that these data were homogeneous and that there were no significant differences in creatinine levels in the three groups of rats $(\mathrm{p}>0.05)$.

\section{Analysis of 3-HPMA levels}

The results for the determination of 3-HPMA levels in rat urine normalized by creatinine levels can be seen in Figure 3. Statistical analysis also showed that the data of each group were homogeneous and displayed significantly different effects $(\mathrm{p}<0.05)$. The analyte in urine sample can be seen in Figure 4.

The levels of 3-HPMA in the urine of the negative control group (Group 1) were lower than in other groups. These results were indicated that 3-HPMA naturally forms in the urine of rats in very low amounts. 

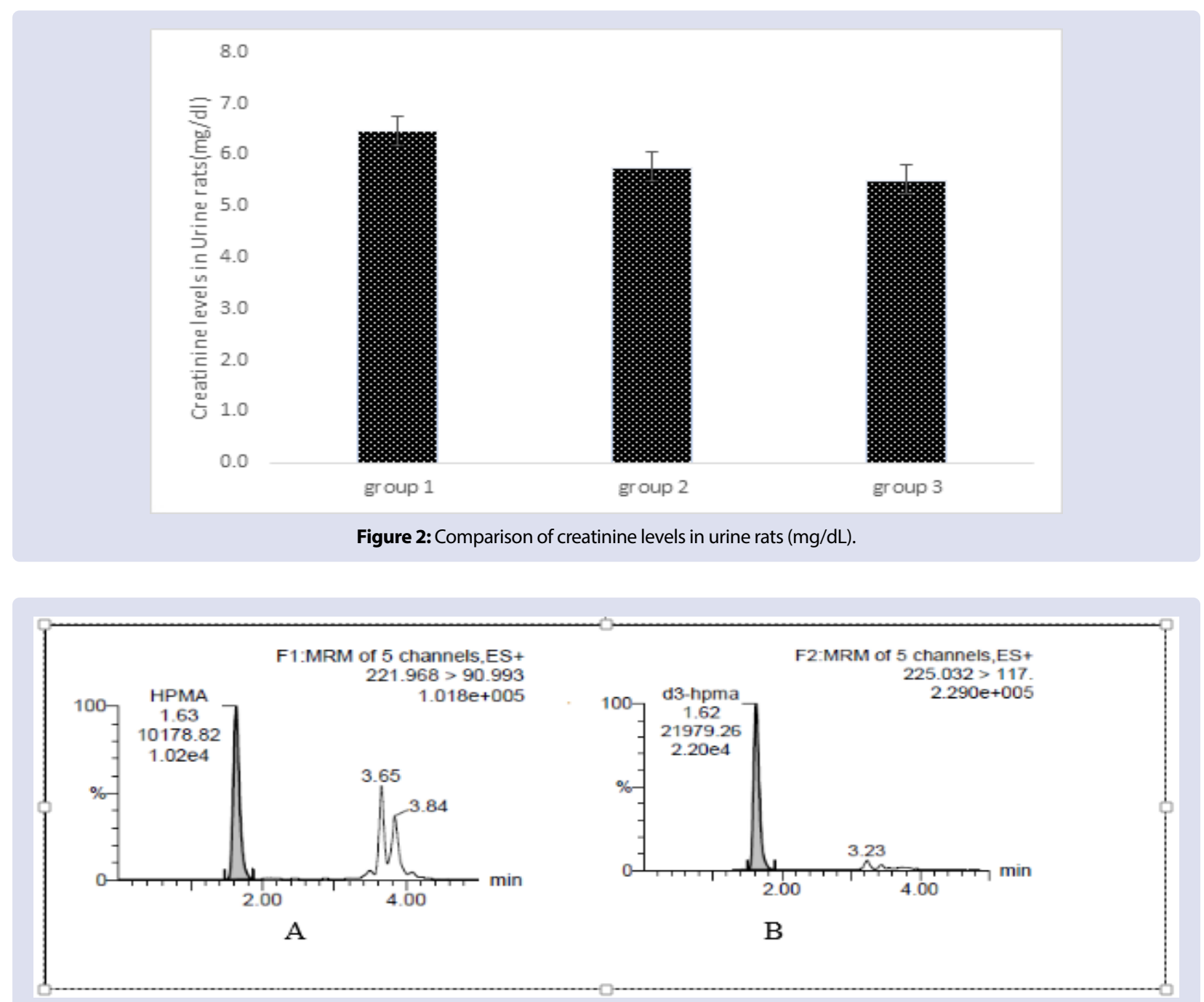

Figure 3: Chromatogram ion 3-HPMA (A) and 3-HPMA-d3 (B) in urine rat sample.

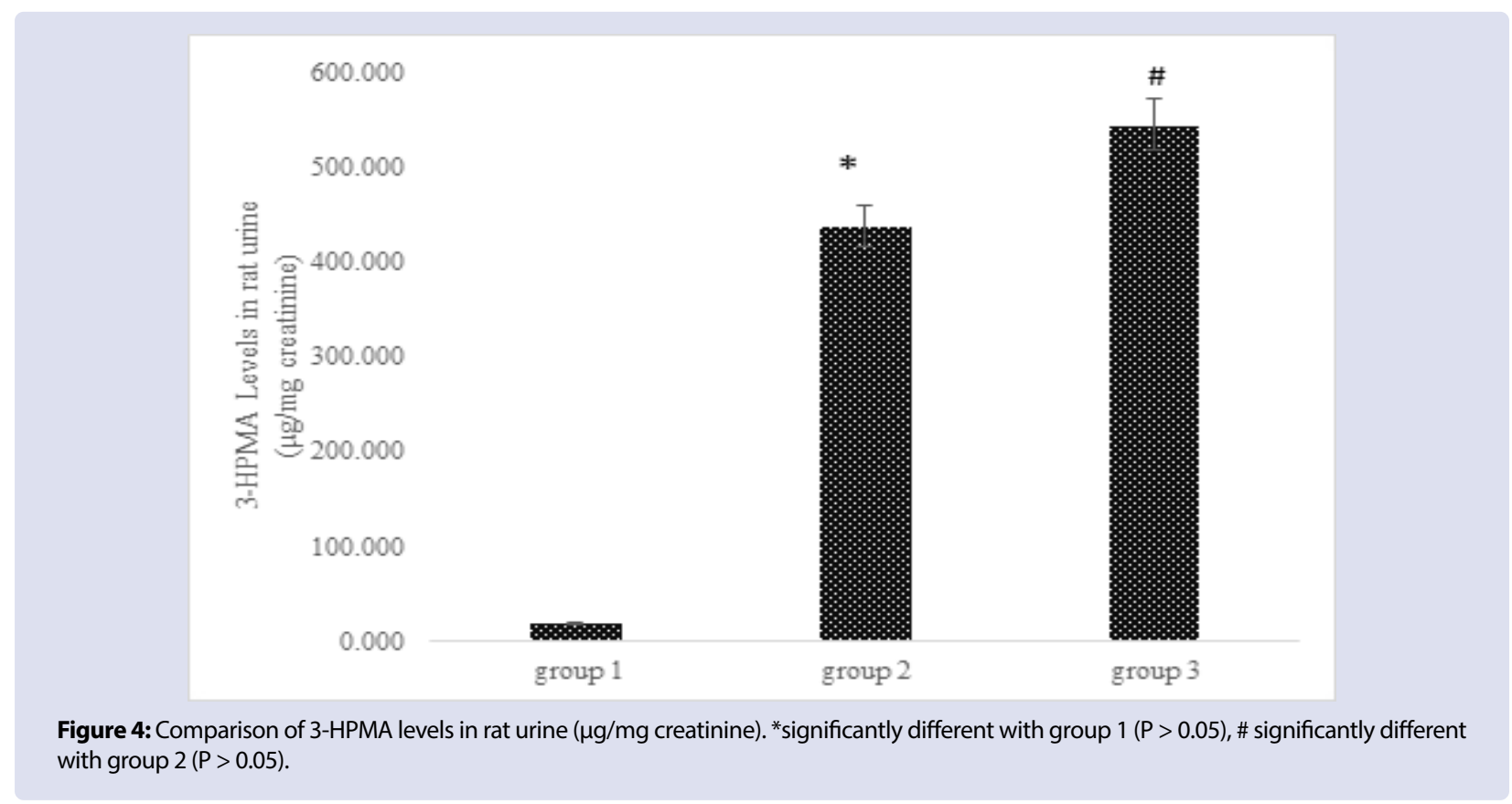



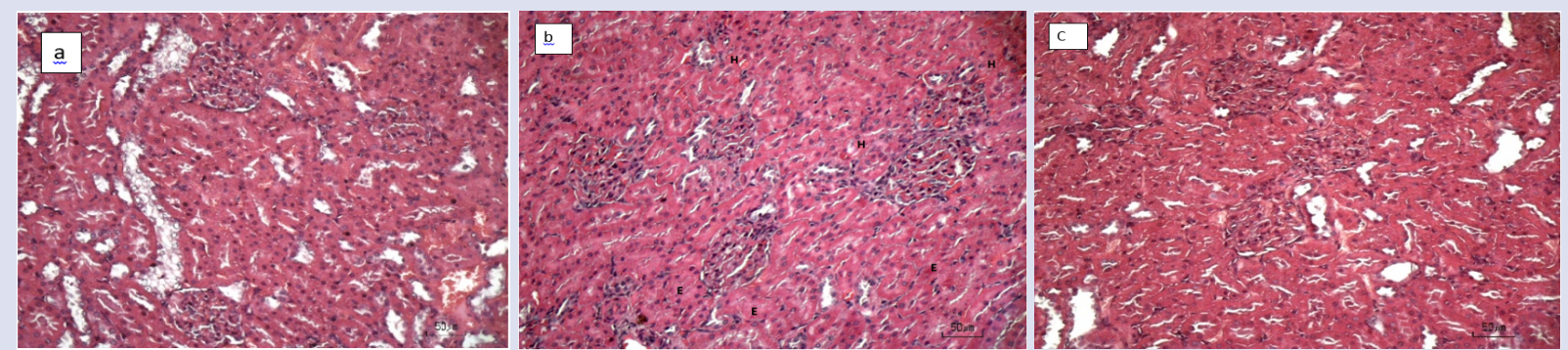

Figure 5: H\&E stained kidney section (H\&E, 20x), a. the control group showed normal condition b. cyclophosphamide induced rats showed glomerular lesion, tubular lesion, edema and haemorrhage in interstitium c. cyclophosphamide induced rats with Leucaena leucocephala (Lam.) de Wit extract showed similar with control group.

The amount of urine 3-HPMA in Group 2 increased significantly compared to Group 1, which indicates the effect of cyclophosphamide on the amount of 3-HPMA produced ${ }^{16}$. Acrolein produced from the metabolism of cyclophosphamide is neutralized by the body through a reaction with glutathione, so that 3-HPMA levels increase. The levels of urine 3-HPMA in Group 3 were significantly different with the levels of urine 3-HPMA in Group 2 ( $\mathrm{p}<0.05)$. These results indicate that administering Leucaena leucochepala (Lam) de Wit seed extract in Group 3 had a significant effect.

\section{Histhopathological examination}

As demonstrated in Figure 5. cyclophosphamide induced rat showed glomerular lesion, tubular lesion, as well as edema and haemorrhage in interstitium. Moreover, the cyclophosphamide induced rat with Leucaena leucocephala (Lam.) de Wit extract show the normal condition. Similar to the control group.

\section{DISCUSSION}

In summary, 3-HPMA analysis was performed on rat urine collected within $24 \mathrm{~h}$. The volume of urine collected differed among the various rat groups. Therefore, 3-HPMA levels in urine were normalized to urine creatinine values. Creatinine can used to correct hydration status, because the production is constant and eliminated at stable rate between individuals. Therefore, dividing the chemical compound level by the creatinine value can eliminate variations between individuals due to urine dilution. ${ }^{27}$ Gender, body mass index, age, race, free fat mass and kindey failure were influenced urinary creatinine levels. ${ }^{27}$ The treatment of rats led to no significant effects in terms of creatinine levels in the various groups. The rats were homogeneous in age and weight, so the results revealed that biological factors had no effect on urine creatinine levels. The differences in creatinine levels in the urine of individual rats were more influenced by hydration factors. The lower the total volume of urine excreted per day, the higher the urinary creatinine levels. ${ }^{27}$ Therefore, creatinine levels can be used to correct the volume of urine excreted.

Moreover, 3-HPMA levels in rat urine were analyzed using a validated method; 3-HPMA is a metabolite from the reaction of acrolein with glutathione, which is excreted in the urine. ${ }^{21}$ Acrolein is naturally found in food and is produced by heating organic matter, cigarettes, engine exhaust combustion, and steam due to the excessive heating of oil. In vivo acrolein is a metabolite product of the anticancer drug cyclophosphamide. ${ }^{20}$

The sulfhydryl compound reacts by reducing acrolein, which leads to the elimination of the side effects of acrolein. ${ }^{17}$ The $70 \%$ ethanolic extract of seeds in this study contained a sulfhydryl concentration equivalent to $29.878 \mathrm{mg} / 100 \mathrm{~g}$. The sulfhydryl compounds contained in the Leucaena leucochepala (Lam) de Wit seeds are expected to act similarly to garlic extract in improving the side effects of cyclophosphamide. ${ }^{17}$
The activity of thiol/sulfhydryl compounds is associated with their ability to induce the signaling of the Nrf2 pathway (nuclear factor 2) and can affect glutathione metabolism in the body. ${ }^{28,29}$ Glutathione in the body functions as an antioxidant that can reduce reactive oxygen compounds derived from acrolein. Glutathione with glutamyl transpeptidase cysteineylglycine $\mathrm{N}$-acetyltransferase enzyme will form 3-HPMA metabolites, which are unreactive and water soluble and are excreted in urine. ${ }^{30}$ The amount of glutathione in the body can be increased through the use of supplements, especially those containing cysteine ester compounds. ${ }^{16}$ Based on the study results, Leucaena leucochepala (Lam) de Wit seed extract plays a role in increasing the amount of 3-HPMA.

Based on histophatological examination, cyclophosphamide induced cause degeneration in kidney jar. Cyclophosphamide in the body will produce acrolein and can causes oxidative stress. ${ }^{29}$ The oxidative stress state in the body will activate nuclear factor kaffa B (Nf-kB) and will increase inflammatory cytokine factors such as nitric oxide (NO), tumor necrosis factor- $\alpha$ (TNF- $\alpha$ ), interleukin-1 $\beta$ (IL-1 $\beta$ ), IL6 and cyclooxygenase-II (COX-II). These changes lead imbalance between inflammatory factors and antioxidants. ${ }^{29}$ When a state of oxidative stress was identified, Nrf2 will play a role in cell protection through ARE activation and affect the glutathione synthesis pathway, glutathione peroxidase activity and enzymes and can play a role in phase 1 and 2 metabolism in the detoxification process, antioxidant and anti-inflammatory effects. ${ }^{29}$ Natural ingredients containing antioxidants and sulfhydryl compounds have been shown to increase the expression and activity of Nrf2. ${ }^{28}$ Leucaena leucocephala (Lam.) de Wit seed contain sulfhydryl compounds and may increase Nrf2 expression, and can protect from cell damage even though they were given cyclophosphamide injection.

\section{CONCLUSION}

In short, 3-HPMA as an analysis method for rat urine was valid and can be applied in assays as demonstrated. Levels of creatinine can be used to correct urine volume. The $70 \%$ ethanolic extract of Leucaena leucochepala (Lam) de Wit seed can increase the amount of 3-HPMA in rat urine and possess potential to ameliorate the side effects of cyclophosphamide. Concentrations of 4-hydroxycyclophophamide in plasma must be assayed to determine the interaction of the active metabolite cyclophosphamide with the extract.

\section{ACKNOWLEDGEMENTS}

We thank to Universitas Indonesia for providing financial support for Doctoral Grant number NKB-3189/UN2.RST/HKP.05.00/2020.

\section{REFERENCES}

1. Matz EL, Hsieh MH. Review of advances in uroprotective agents for cyclophosphamide- and ifosfamide-induced hemorrhagic cystitis Urology. 2017;100:16-9. 
2. Ogino MH, Tadi P. Cyclophosphamide. [Updated 2020 May 23]. In: StatPearls [Internet]. Treasure Island (FL): StatPearls Publishing; 2020 Jan-. Available from: https://www.ncbi.nlm.nih.gov/books/ NBK553087/

3. Małyszko J, Kozłowska K, Kozłowski L, Małyszko J. Nephrotoxicity of anticancer treatment. Nephrol Dial Transplant. 2017;32(6):924-936

4. Doshi BR, Sajjan VV, Manjunathswamy BS. Managing a side effect: Cyclophosphamide-induced hemorrhagic cystitis. Indian J Drugs Dermatology. 2019;5:66-71

5. Tanaka T, Nakashima Y, Sasaki H, Masaki M, Mogi A, Tamura K, et al. Severe hemorrhagic cystitis caused by cyclophosphamide and capecitabine therapy in breast cancer patients: two case reports and literature review. Case Rep Oncol. 2019;12(1):69-75

6. Emadi A, Jones RJ, Brodsky RA. Cyclophosphamide and cancer: golden anniversary. Nat Rev Clin Oncol. 2009;6(11):638-47.

7. Pitto $\mathrm{CM}$, García-Perdomo HA. Interventions to treat hemorrhagic cystitis: a systematic review and meta-analysis. Support Care Cancer. 2017;25(7):2043-6

8. Baruah M. Oncologic emergencies: a review. Int J Res Med Sci. 2018:6(5):1484-1490.

9. Ribeiro RA, Lima-junior RCP, Leite CAVG, Mota JMSC, Macedo FYB, Lima MVA, et al. Chemotherapy-induced hemorrhagic cystitis : pathogenesis, pharmacological approaches and new insights. J Exp Integr Med. 2012;2(2):95-112.

10. Robinson D, Schulz G, Langley R, Donze K, Winchester K, Rodgers C. Evidence-based practice recommendations for hydration in children and adolescents with cancer receiving intravenous cyclophosphamide. J Pediatr Oncol Nurs. 2014;31(4):191-9.

11. Hanly LN, Chen N, Aleksa K. N-acetylcysteine as a novel prophylactic treatment for ifosfamide-induced nephrotoxicity in children : translational pharmacokinetics. J Clin Pharmacol. 2012;52:55-64.

12. Kim SH, Lee IC, Baek HS, Shin IS, Moon C, Bae CS, et al. Mechanism for the protective effect of diallyl disulfide against cyclophosphamide acute urotoxicity in rats. Food Chem Toxicol. 2014;64:110-8.

13. Kim SH, Lee IC, Ko JW, Moon C, Kim SH, Shin IS, et al. Diallyl disulfide prevents cyclophosphamide-induced hemorrhagic cystitis in rats through the inhibition of oxidative damage, MAPKs, and NF- $\mathrm{K}$ B pathways. Biomol Ther. 2015;23(2):180-8.

14. Sumiyoshi $\mathrm{H}$, Wargovich MJ. Cancer in mice by naturally occurring organosulfur compounds chemoprevention of 1, 2-dimethylhydrazineinduced colon cancer in mice by naturally occurring organosulfur compounds. Cancer Res. 1990;50(August):5084-7.

15. Bhatia K, Ahmad F, Rashid H, Raisuddin S. Protective effect of S -allylcysteine against cyclophosphamide-induced bladder hemorrhagic cystitis in mice. Food Chem Toxicol. 2008;46(August):3368-74.

16. Conklin DJ, Haberzettl P, Lesgards J-F, Prough RA, Srivastava S, Bhatnagar A. Increased sensitivity of glutathione S-transferase P-null mice to cyclophosphamide-induced urinary bladder toxicity. J Pharmacol Exp Ther.2009;331(2):456-69.
17. El-Sebaey AM, Abdelhamid FM, Abdalla OA. Protective effects of garlic extract against hematological alterations, immunosuppression, hepatic oxidative stress, and renal damage induced by cyclophosphamide in rats. Environ Sci Pollut Res. 2019;26:15559-72.

18. Suvachittanont W, Kurashima Y, Esumi H, Tsuda M. Formation of thiazolidine-4-carboxylic acid (thioproline), an effective nitrite-trapping agent in human body, in Parkia speciosa seeds and other edible leguminous seeds in Thailand. Food Chem. 1996:55(4):359-63.

19. Afkhami-Ardakani M, Hassanzadeh S, Shahrooz R, Asadi-Samani M, Latifi E, Luther T. Phytotherapy and phytopharmacology for reduction of cyclophosphamide-induced toxicity in the male urinary system. J Ren Inj Prev. 2017;6(3):164-70.

20. Moghe A, Ghare S, Lamoreau B, Mohammad M, Barve S, McClain C et al. Molecular mechanisms of acrolein toxicity: relevance to human disease. Toxicol Sci. 2015:143(2):242-55.

21. Yoshida M, Mikami T, Higashi K, Saiki R, Mizoi M, Fukuda K, et al. Inverse correlation between stroke and urinary 3-hydroxypropy mercapturic acid, an acrolein-glutathione metabolite. Clin Chim Acta. 2012;413(7-8):753-9.

22. Tully M, Zheng L, Shi R. Acrolein detection: Potential theranostic utility in multiple sclerosis and spinal cord injury. Expert Rev Neurother. 2014;14(6):679-85.

23. Wardatun S, Harahap Y, Mun'im A, Saputri FC, Sutandyo N Leucaena leucocephala (Lam.) de Wit seeds: A new potential source of sulfhydryl compounds. Pharmacogn J. 2020;12(2):298-302.

24. Europen Medicines Agency (EMEA). Guideline on bioanalytical method validation. Committee for Medicinal Products for Human Use (CHMP). EMEA Website. https://www.ema. europa. eu/documents/ scientific-guideline/guideline-bioanalytical-method-validation_en.pdf. July 21, 2011

25. Food and Drug Administration (FDA). Bioanalytical method validation guidance for industry. U.S Department of Health and Human Services. Food Drug Administration, Center for Drug Evaluation and Research (CDER). US Department of Center for Veterinary Medicine (CVM). February 8, 2019. https://www.fda.gov/downloads/drugs/ guidances/ucm070107.pdf

26. Harahap Y, Yanuar A, Muhammad C, Melhan M, Purwanto DJ. Quantification of 3-hydroxypropyl mercapturic acid in the urine of patients with breast cancer to monitor cyclophosphamide toxicity. Ther Drug Monit. 2020;42(4):548-53.

27. O'Brien KM, Upson K, Buckley JP. Lipid and creatinine adjustment to evaluate health effects of environmental exposures. Curr Environ Heal reports. 2017:4(1):44-50

28. Waz S, Heeba GH, Hassanin SO, Abdel-latif RG. Nephroprotective effect of exogenous hydrogen sulfide donor against cyclophosphamide-induced toxicity is mediated by Nrf2/HO-1/NF-KB signaling pathway. Life Sci. 2021;264:118630.

29. Molaei E, Molaei. A, Farshad A, Hayes WA, Karimi G. Nephroprotective activity of natural product against chemical toxicant: The role of Nrf2/ ARE signaling pathway. Food Sci Nutr. 2021:9:3362-84.

30. Higashi K, Igarashi K, Toida T. Recent progress in analytical methods for determination of urinary 3-hydroxypropylmercapturic acid, a major metabolite of acrolein. Biol Pharm Bull. 2016;39(6):915-9. 


\section{GRAPHICAL ABSTRACT}

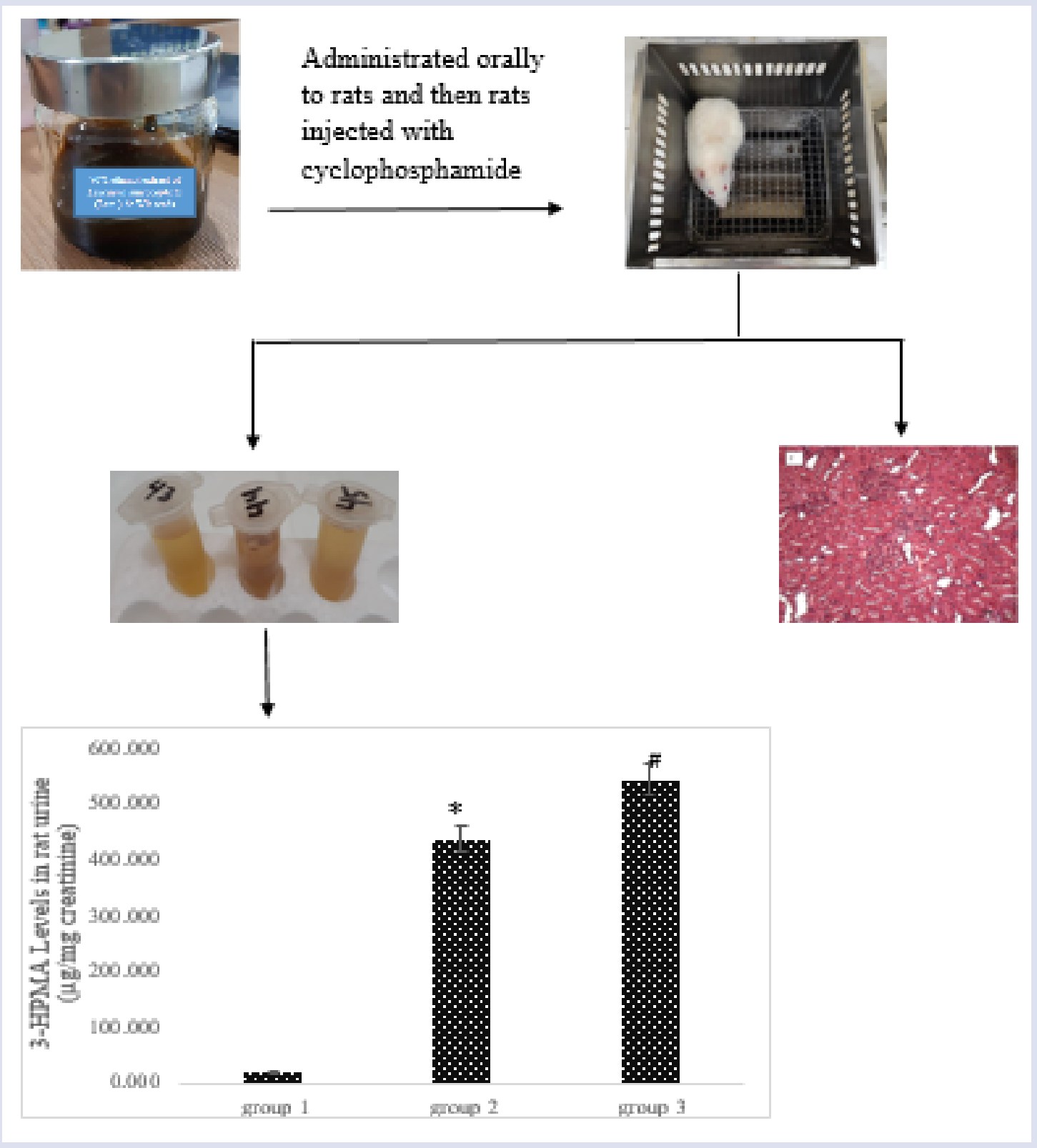

\section{SUMMARY}

A 70\% ethanolic extract of Leucaena leucocephala (Lam.) de Wit seeds contain a certain amount of sulfhydryl active compounds and potential for ameliorated cyclophosphamide side effects. The extract was administered to a rat model for cyclophosphamide-induced hemorrhagic cystitis. The rats urine were collected for 24 hours and analyzed for the amount of 3-HPMA, furthermore histhopathological examination were performed on the kidneys. The results showed $70 \%$ ethanolic extract can increase the amount of 3-HPMA in rat urine and there was ameliorated in hemorrhagic cystitis kidney tissue. The $70 \%$ ethanolic extract of seeds displayed a potential ameliorating effect against cyclophosphamide side effects. 


\section{ABOUT AUTHORS}

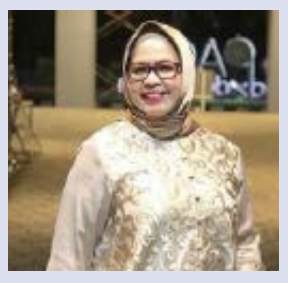

Yahdiana Harahap has completed her PhD from Department of Pharmacy, Institute Technology Bandung, Indonesia. Her expertise is Pharmaceutical Chemistry especially Bioanalysis related to Bioavailability/Bioequivalence Studies, Therapeutic Drug Monitoring, and Carcinogenic of DNA-Adduct. Now she is the Dean of Faculty of Pharmacy, Indonesia Defense University and Head of Bioavailability and Bioequivalence Laboratory Faculty of Pharmacy, Universitas Indonesia. Prior to this position, she was the Dean of Faculty of Pharmacy, Universitas Indonesia. Besides the academic position, she is also active in scientific organizations, such as Asian Federation of Pharmaceutical Sciences and since 2020 assigned as President. As researcher, she has published 91 papers published in International Journals with Scopus Index. She has been invited to be the speakers in many international conferences, especially in the field of Bioequivalence Studies and Bioanalysis technique. She is also got a lot of awards, among them is The Ishidate Awardee from Federation of Asian Pharmaceutical Association in the field of Pharmacy Education, 2016 in Bangkok. Since 2020 she becomes The Associate Editor in Pharmacy Education Editorial Panel, International Pharmaceutical Federation (FIP). She currently serves as The Narcotics Law Drafting Team at Ministry of Health Republic of Indonesia and National Agency of Drug and Food Control (NADFC), especially in Bioequivalence Studies evaluation. She is also an assessor of ISO 17025 under National Accreditation Committee (KAN) since 2010 and as assessor and validator of LAM-PTKes since 2020.

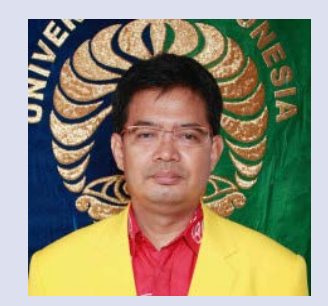

Abdul Mun'im is Professor in Department of Pharmacognosy-Phytochemistry, Faculty of Pharmacy, Universitas Indonesia. Currently, the research focused on extraction methods, separation, isolation and structure elucidation of analysis bioactive compounds. Bioassay in vitro and in vivo of Indonesian medicinal plants and their biomarker.

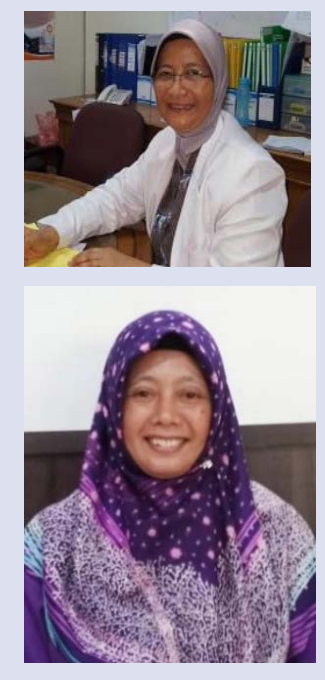

Noorwati Sutandyo is PhD in Faculty of Medicine Science, Universitas Indonesia. She is a lecturer in Internal Medicine Program Study. She is also oncology doctor in Cancer Dharmais Hospital, Jakarta.

Sri Wardatun is a PhD Student at Departement of Pharmaceutical Science, Faculty of Pharmacy, Universitas Indonesia. Develops work in the area of Pharmaceutical Chemisty and Pharmacobotany.

Cite this article: Wardatun S, Harahap Y, Sutandyo N, Mun'im A. Analyzing of Urine 3-Hidroxy Propil Mercapturic Acid on Cyclophosphamide Induced Rat to Determine Ameliorating Effect of Leucaena leucocephala (Lam.) de Wit Seed Extract. Pharmacogn J. 2021;13(6)Suppl: 1549-1556. 